1

\title{
Characterization of Southeast Asia mangoes (Mangifera indica L) according to their physicochemical attributes
}

Tamunonengiyeofori Lawson ${ }^{\mathrm{a}, \mathrm{b}}$, Grantley W. Lycett ${ }^{\mathrm{b}}$, Asgar Ali $^{\mathrm{a}}$, Chiew Foan Chin ${ }^{\mathrm{a}^{*}}$

${ }^{a}$ School of Biosciences, Faculty of Science, The University of Nottingham Malaysia Campus, Jalan Broga, 43500 Semenyih, Selangor, Darul Ehsan, Malaysia

${ }^{\mathrm{b}}$ Division of Plant and Crop Sciences, School of Biosciences, University of Nottingham, Sutton (1) Bonington Campus, Loughborough, LE12 5RD, UK

*Corresponding author: Chiew Foan Chin, Email: chiew-foan.chin@nottingham.edu.my Phone: +6 (03) 89248216 6 17

8

9
\section{(1)}




\section{Abstract}

27 Mango (Mangifera indica.L.) is an economically important fruit crop grown in the tropics. One of the important traits of mango for successful commercial production is the storage quality of the fruit. This study was conducted to evaluate the postharvest qualities of three mango (Mangifera indica) varieties namely 'Chokanan', 'Golden phoenix' and 'Water lily' grown in Southeast Asia regions. The study found that variety and ripening stage had an impact on the postharvest qualities. In general, an increase in weight loss, $\mathrm{L}^{*}$ value and soluble solids concentration (SSC) along with a reduction in titratable acidity (TA), firmness and hue value as ripening progressed were observed irrespective of the variety. Analysis of variance and multivariate analysis were used to characterize the ripening process. This study provides useful information for devising strategies in postharvest handling and implementation of breeding programs for mango crop improvement.

Abbreviations: N, Newtons; SSC, soluble solid content; TA, titratable acidity; PCA, principal component analysis

Keywords: Ethylene production; fruit ripening; Mangifera indica L; respiration rate; physicochemical characteristics; varieties.

(1) 


\section{Introduction}

Mango (Mangifera indica L.) is one of the most important tropical fruit crops with significant commercial value. Mango fruit is widely consumed globally due to its juiciness, delicious taste, exotic flavor and nutritional value. In addition, mango fruit is a rich source of health promoting compounds such as carotenoids, ascorbic acids, quercetin and mangiferin (Lauricella et al., 2017). Currently, Asia is the largest mango-producing region, with a production of 34.6 million tons, which accounts for $74.30 \%$ of global mango production. This is followed by America (13.00\%; 4 million tons), Africa (11.00\%; 3 million tons) and a very little portion from Oceania (0.10\%; 0.04 million tons) (FAOSTAT, 2016). There are thousands of mango varieties which are distributed worldwide. Of which, Asia has over 500 fully characterized varieties (Singh et al., 2016). However, only a few of these available mango varieties are traded internationally while most are grown for local consumption (Kuhn et al., 2017). Commercial mango varieties that dominate the global export market include 'Tommy Atkins', 'Haden', 'Ataulfo', 'Kent', 'Keitt' and 'Alphonso' (Bally, 2011; Galán Saúco, 2015; Nassur et al., 2015). Mango varieties in Malaysia include 'Chokanan', 'Harumanis', 'Sala', 'Masmuda' and 'Maha 65' amongst others (MOA, 2016). However, these varieties have not attained equal international popularity as compared to Indian or Floridian varieties due to lack of research attention (Abu Bakar and Fry, 2013).

Fruit ripening involves a spectrum of significant physiological, biochemical and molecular changes that give rise to an edible fruit of desired quality (Barry and Giovannoni, 2007). An increased rate of respiration and ethylene production during ripening has been documented extensively in climacteric fruit such as papaya (Ong et al., 2013) as well as in mango ripening process (Khaliq et al., 2015; Palafox-Carlos et al., 2015; Zerbini et al., 2015). The period of fruit 
ripening is also characterized with an increase in sugar content and color changes (PalafoxCarlos et al., 2015; Ibarra-Garza et al., 2015). Mango peel color changes facilitate the identification of the appropriate maturity stage for harvesting and consumption albeit not all varieties change from green to yellow/orange upon ripening (Yahia, 2011). Mango ripens within 4-9 days (variety dependent) (Carrillo-Lopez et al., 2000; Srivastava et al., 2016) although there has been reports on 'Alphonso' and 'Banganapalli' mangoes with a ripening duration of 12-18 days from harvest (Deshpande et al., 2017; Nambi et al., 2015). At cold storage $\left(13{ }^{\circ} \mathrm{C}\right)$, mango can be stored for up to 2-3 weeks (Carrillo-Lopez et al., 2000).

As postharvest qualities may differ according to varieties, it is necessary to carry out specific studies on each local mango variety in order to uncover their potential to become a commercial marketable fruit. Such information will provide an insight into the development of postharvest strategies towards mango fruit quality improvement and open new marketing opportunities to the farmers and to the local industry. To date, only a few published results on the physicochemical and physiological profile of locally produced mangoes in the literature are available (Bejo and Kamaruddin, 2014; Mansor et al., 2011; Khaliq et al., 2015; Zakaria et al., 2012). Therefore, the objectives of this study were to evaluate the effect of ripening on the physicochemical characteristics and physiological behavior of 'Chokanan', 'Golden phoenix' and 'Water lily' mango varieties, which are grown in the Southeast Asia regions.

\section{Materials and Methods}

\subsection{Mango samples}

Mature green mangoes (Mangifera indica vars. 'Chokanan', 'Golden phoenix' and 'Water lily') of maturity index 2 (FAMA, 2017) were purchased from a mango farmer in Malacca, Malaysia. 
Mango fruit were selected for uniformity in size, shape and absence of external injury. After sorting, fruit were washed, dried and allowed to ripen at ambient temperature $\left(25 \pm 1{ }^{\circ} \mathrm{C}, 80 \pm 5\right.$ $\%$ relative humidity). Assessment of postharvest quality parameters were observed on arrival (0th day) and at 2 day intervals of the ripening period. At each evaluation time, four replicates consisting of three individual fruit per replicate were randomly sampled for each mango variety. The analyses were conducted at the Postharvest Laboratory, School of Biosciences, University of Nottingham Malaysia Campus.

\subsection{Determination of physicochemical parameters}

Evaluation of physicochemical parameters was carried out as reported by Ali et al., (2016). Weight loss determination was obtained by weighing mango on the 0th day of storage and at 2 day intervals over the storage period. The percentage weight loss was calculated relative to the initial weight.

Peel color was assessed on the basis of the Hunter Lab System using a MiniScan XE Plus colorimeter and presented in the values of $\mathrm{L}^{*} \mathrm{a}^{*} \mathrm{~b}^{*}$ and $\mathrm{h}^{\circ}$. The $\mathrm{L}^{*}$ coordinate indicates brightness of color with values ranging from $0=$ black to $100=$ white. Coordinates, $\mathrm{a}^{*}$ and $\mathrm{b}^{*}$, indicate color directions: $+\mathrm{a}^{*}$ is the red direction, $-\mathrm{a}^{*}$ is the green direction, $+\mathrm{b}^{*}$ is the yellow direction, and $-b^{*}$ is the blue direction. From these values, hue angle $\left(h^{\circ}\right)$ was calculated as $h^{\circ}=$ tangent $\left.{ }^{-1} \mathrm{~b}^{*} / \mathrm{a}^{*}\right)$ where $0^{\circ}=$ red purple, $90^{\circ}=$ yellow, $180^{\circ}=$ blue-green and $270^{\circ}=$ blue. Fruit firmness was assessed using an Instron Universal Testing Machine (Instron 2519-104, Norwood, MA). Measurements were taken from three points of the equatorial region for each sampled fruit. An average of three readings was obtained and expressed in Newtons $(\mathrm{N})$. The same fruit pulp samples $(10 \mathrm{~g})$ used in the firmness evaluation were homogenized using a kitchen blender (Philip, Malaysia) with $40 \mathrm{ml}$ of distilled water, and filtered through a double layer of muslin 
cloth to extract juice for further analyses. Soluble solid content (SSC) was determined with a droplet of the filtrate using a Palette Digital Refractometer (Model: PR-32 $\alpha$, Atago Co Ltd., Japan) and expressed as a percentage (\%). Titratable acidity (TA) was determined by titration of $5 \mathrm{ml}$ of filtrate with $0.1 \mathrm{~N} \mathrm{NaOH}$ to an endpoint of $\mathrm{pH} 8.1$ by two drops of $0.1 \%$ phenolphthalein indicator. The results are expressed as a percentage of citric acid equivalents.

\subsection{Respiration and ethylene production}

The respiration and ethylene production of mango fruit were carried out as described by Ong et al., (2013). Fruit were placed in a plastic container tightly sealed with a lid. After 1 hour of incubation, $1 \mathrm{ml}$ of gas sample was withdrawn from the headspace and analyzed in the gas chromatograph (GC) (Clarus-500 Perkin-Elmer, USA) equipped with a column (Agilent J\&W, DB-5MS column: $30 \mathrm{~m}$ in length, $0.25 \mathrm{~mm}$ in diameter and $0.25 \mu \mathrm{m}$ in film thickness) with two detectors connected in series; a thermal conductivity detector (TCD) and flame ionization detector (FID) for the quantification of carbon dioxide $\left(\mathrm{CO}_{2}\right)$ and ethylene respectively. Helium was used as the carrier gas for thermal conductivity (TCD) and temperatures were $60{ }^{\circ} \mathrm{C}, 150{ }^{\circ} \mathrm{C}$ and $200{ }^{\circ} \mathrm{C}$ for the oven, injector and detector respectively. The injector, oven and detector temperatures were $200{ }^{\circ} \mathrm{C}, 120^{\circ} \mathrm{C}$ and $250^{\circ} \mathrm{C}$ respectively with nitrogen as the carrier gas for the flame ionization detector (FID). Concentration of the standards used was $1.0 \% \mathrm{CO}_{2}$ and 1 ppm ethylene $\left(\mathrm{C}_{2} \mathrm{H}_{4}\right)$. Respiration and ethylene production rate are expressed as $\mathrm{nmol} \mathrm{kg}^{-1} \mathrm{~s}^{-1}$ according to Banks et al., (1995).

\subsection{Statistical analysis}

The experiments were conducted according to a completely randomized design (CRD) in four replications. For each replicate, three fruit were randomly selected for analysis at each evaluation time. Data were subjected to analysis of variance (ANOVA) using the GENSTAT (18th edition) 
software. Means were separated using Duncan's Multiple Range Test (DMRT; p < 0.05). Multivariate analysis was carried out using the XLSTAT (Addinsoft, New York, USA). PCA was performed to predict the total variability between days of ripening and mango varieties. The Pearson's correlation coefficient was employed to explore the relationship between the postharvest parameters.

\section{Results}

\subsection{Changes in physical quality parameters}

Based on the external appearance and postharvest changes score, 'Golden phoenix', 'Water lily' and 'Chokanan' mango varieties were found to achieve ripeness at 7, 7 and 9 days respectively.

\subsubsection{Weight loss}

A progressive weight loss was observed during ripening for all the varieties under study (Fig. 1). It increased significantly $(\mathrm{p}<0.05)$ over the ambient storage period. 'Chokanan' variety exhibited a $2.3 \%$ weight loss after two days of storage (Fig 1a). The highest rate of weight loss $(6.98 \%)$ was noticed on the 8th day of ripening for 'Chokanan' (a mean loss of $0.76 \%$ per day). As can be seen in Fig. 1b, weight loss in 'Golden phoenix' variety significantly increased ( $\mathrm{p}<$ $0.05)$ from the 2 nd $(2.76 \%)$ to 4 th day $(5.78 \%)$. The percentage weight loss observed on the 4 th day was not significantly different $(\mathrm{p}<0.05)$ from that obtained on the 6th day of ripening. At the end of storage, 'Golden phoenix' had lost $7.76 \%$ of initial weight with an average of $1.20 \%$ per day. 'Water lily' lost $2.48 \%$ of its initial weight after two days of storage and this was maintained with significant differences $(\mathrm{p}<0.05)$ until the 6th day (Fig. 1c). At the end of storage, it attained an $8.44 \%$ weight loss which averaged $1.40 \%$ per day. 


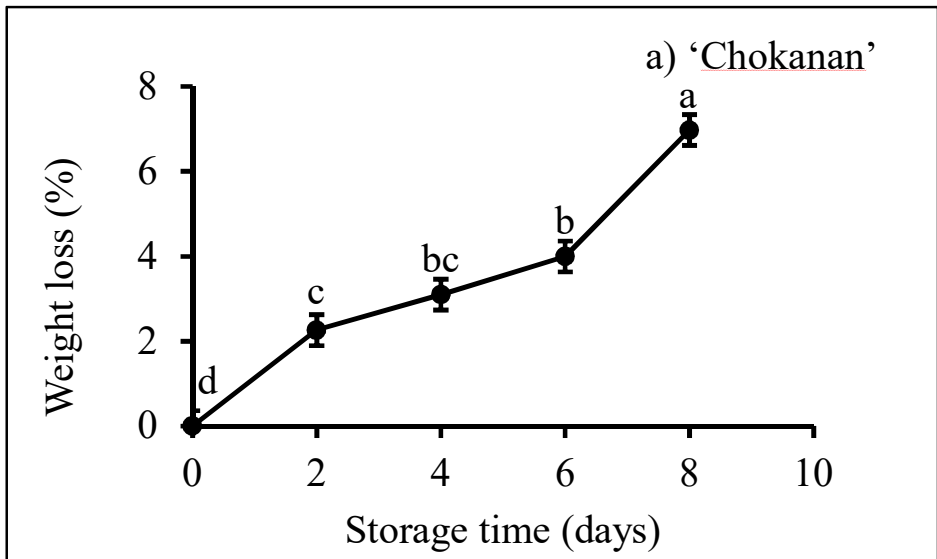

166

167

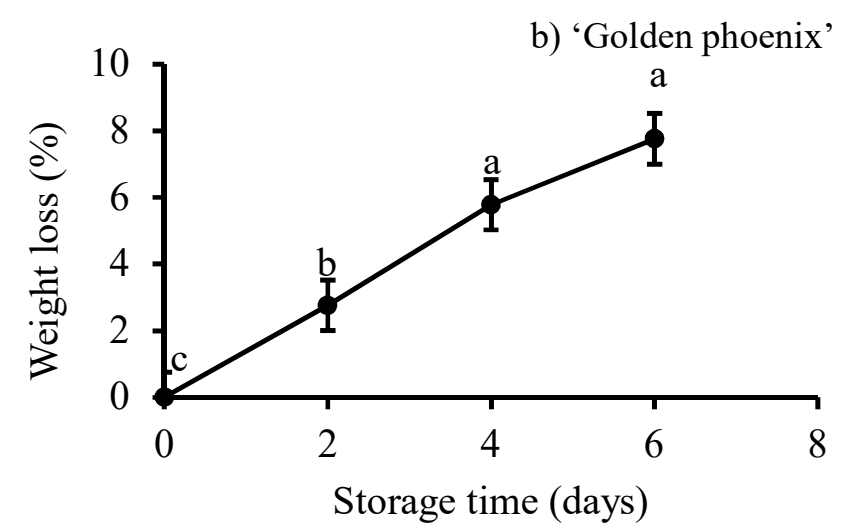

172

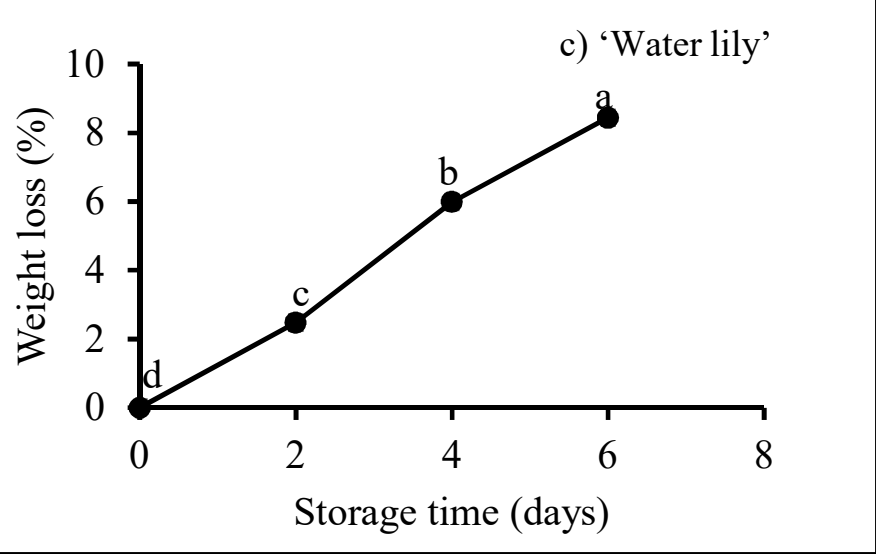

179 Figure 1: Weight loss of a) 'Chokanan', b) 'Golden phoenix' and c) 'Water lily' mango varieties 180 during storage. Note: Vertical bars indicate standard error of mean of four replicates per variety. 181 Different letters indicate significant difference between storage times at $\mathrm{p}<0.05$ for each mango 182 variety 


\subsubsection{Peel color}

The external appearance of each variety at the beginning and end of storage is presented in Fig.

2. Color parameters as influenced by the ripening period are provided in Table 1. As ripening progressed, the peel color changed from green to slightly or full yellow color depending on variety. The visual skin color of 'Chokanan' changed noticeably to yellow during fruit ripening (Fig. 2). The $\mathrm{L}^{*}$ value (lightness) of 'Chokanan' was 53.63 on the 0 th day of storage and gradually increased as the fruit ripening advanced (Table 1). When 'Chokanan' was fully ripened after eight days, there was a significant $(p<0.05)$ increase in lightness to 63.78. 'Chokanan' peel color exhibited a decline in hue angle, which started at 118.20 and was maintained with significant differences from the 2nd to 8 th day of storage (Table 1). An increasing trend was also observed on the peel $\mathrm{a}^{*}$ and $\mathrm{b} *$ values during ripening. 'Golden phoenix' showed no conspicuous changes of peel color from green to yellow upon ripening (Fig. 2). Lightness (L*) value of the 'Golden phoenix' peel increased, beginning on the 2nd day and presented no significant changes until the end of storage. Similarly, there was a gradual increase in peel a* value beginning on the 2nd day, and higher $\mathrm{b}^{*}$ values on day four (Table1). Meanwhile, hue angle dropped progressively from 119.03 to 108.61 during the ripening period. In 'Water lily' variety, hue angle decreased from 120.4 to 103.3 with significant differences $(p<0.05)$ between the storage times (Table 1). A progressive increase in peel a* value beginning on day two, and higher $\mathrm{L}^{*}$ value on day four (Fig. 2) were observed. Similarly, an increasing trend was observed for $b^{*}$ values with significant differences $(p<0.05)$ between storage time. Overall, the peel colors of the three mango varieties under study became lighter (higher $\mathrm{L}^{*}$ values), less green (increased $\mathrm{a}^{*}$ values) and tended to be more yellow (increased $b^{*}$ values) as ripening time progressed. 
(a)

Chokanan variety

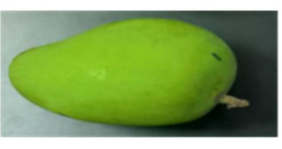

Golden phoenix variety

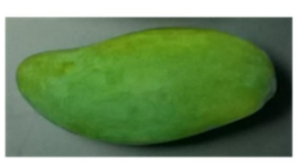

Water lily variety (b)
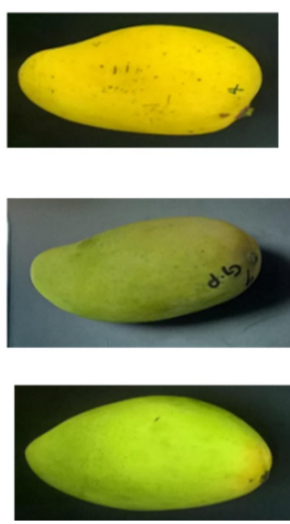

212

213

214

215

Figure 2. External peel color appearance of mango varieties.

(a) Fruit samples on arrival (day 0) and (b) samples at the end of storage (8th day for 'Chokanan' and 6th day for 'Golden phoenix' and 'Water lily' respectively).

Table 1: Changes in peel color in mango (Mangifera indica L.) varieties ('Chokanan', 'Golden phoenix' and 'Water lily') during storage.

\begin{tabular}{ccccc}
\hline $\begin{array}{c}\text { Variety/ } \\
\text { storage time }\end{array}$ & Hue & $\mathrm{L}^{*}$ value & $\mathrm{a}^{*}$ value & $\mathrm{b}^{*}$ value \\
\hline 'Chokanan' & $118.20 \mathrm{a}$ & $53.63 \mathrm{~d}$ & $-16.33 \mathrm{~d}$ & $30.75 \mathrm{~d}$ \\
0 & $116.61 \mathrm{a}$ & $58.46 \mathrm{c}$ & $-15.72 \mathrm{~d}$ & $34.53 \mathrm{c}$ \\
2 & $107.38 \mathrm{~b}$ & $60.22 \mathrm{bc}$ & $-12.76 \mathrm{c}$ & $41.38 \mathrm{~b}$ \\
4 & $101.45 \mathrm{c}$ & $62.53 \mathrm{ab}$ & $-8.96 \mathrm{~b}$ & $43.51 \mathrm{~b}$ \\
6 & $89.63 \mathrm{~d}$ & $63.78 \mathrm{a}$ & $-1.31 \mathrm{a}$ & $53.27 \mathrm{a}$ \\
8 & & & & \\
\hline 'Golden phoenix' & $119.03 \mathrm{a}$ & $49.38 \mathrm{~b}$ & $-15.71 \mathrm{c}$ & $28.70 \mathrm{~b}$ \\
0 & $116.10 \mathrm{~b}$ & $54.80 \mathrm{a}$ & $-14.74 \mathrm{bc}$ & $30.40 \mathrm{~b}$ \\
2 & $110.49 \mathrm{c}$ & $54.83 \mathrm{a}$ & $-13.68 \mathrm{ab}$ & $36.94 \mathrm{a}$ \\
4 & $108.61 \mathrm{c}$ & $57.59 \mathrm{a}$ & $-12.64 \mathrm{a}$ & $37.96 \mathrm{a}$ \\
6 & & & & \\
'Water lily' & $120.40 \mathrm{a}$ & $49.00 \mathrm{~b}$ & $-17.53 \mathrm{c}$ & $29.90 \mathrm{~d}$ \\
0 & $117.00 \mathrm{~b}$ & $52.65 \mathrm{~b}$ & $-17.13 \mathrm{bc}$ & $33.89 \mathrm{c}$ \\
2 & $110.50 \mathrm{c}$ & $57.85 \mathrm{a}$ & $-15.38 \mathrm{~b}$ & $41.10 \mathrm{~b}$ \\
4 & $103.30 \mathrm{~d}$ & $57.92 \mathrm{a}$ & $-11.31 \mathrm{a}$ & $48.20 \mathrm{a}$ \\
\hline
\end{tabular}

Note: $L^{*}, a^{*}$ and $b^{*}$ indicate lightness, indexes of red/green and yellow/blue color of fruit respectively. Hue describes the visual color of the fruit. Values are means of four replicates. Different letters mean significant difference between storage times at $p<0.05$ for each mango variety. 


\subsubsection{Pulp firmness}

241 Over the period of storage time, a loss of pulp firmness was observed in all mango varieties under study. Firmness of 'Chokanan' decreased significantly $(p<0.05)$ during storage from $138.18 \mathrm{~N}$ to $12.67 \mathrm{~N}$ after eight days (Fig. 3a). There were no significant firmness changes during the first two days. A rapid loss of firmness (82.86 \%) took place in 'Chokanan' between 2nd and 6th day of storage, with slow changes thereafter. In 'Golden phoenix', decline in firmness which started at $109.22 \mathrm{~N}$ was maintained with significant differences $(\mathrm{p}<0.05)$ between sampling points (Fig.3b). A significant decrease in firmness had begun on the second day by up to $36 \%$ for 'Golden phoenix'. Firmness values at the end of storage $(9.53 \mathrm{~N})$ resulted in total loss of $91.27 \%$ of the firmness recorded compared to the beginning of the study. For 'Water lily' variety, the firmness value decreased significantly during storage from 104.47 to $7.50 \mathrm{~N}$ after six days (Fig. 3c). A sharp decline was observed until the 4th day of ripening ( $16.61 \mathrm{~N}, 84 \%$ loss), whereas from the 4th to the 6th day of ripening, the loss in fruit firmness remained negligible. At the end of the ripening period, 'Water lily' had lost $92.82 \%$ of its initial fruit firmness.

254

255

256 

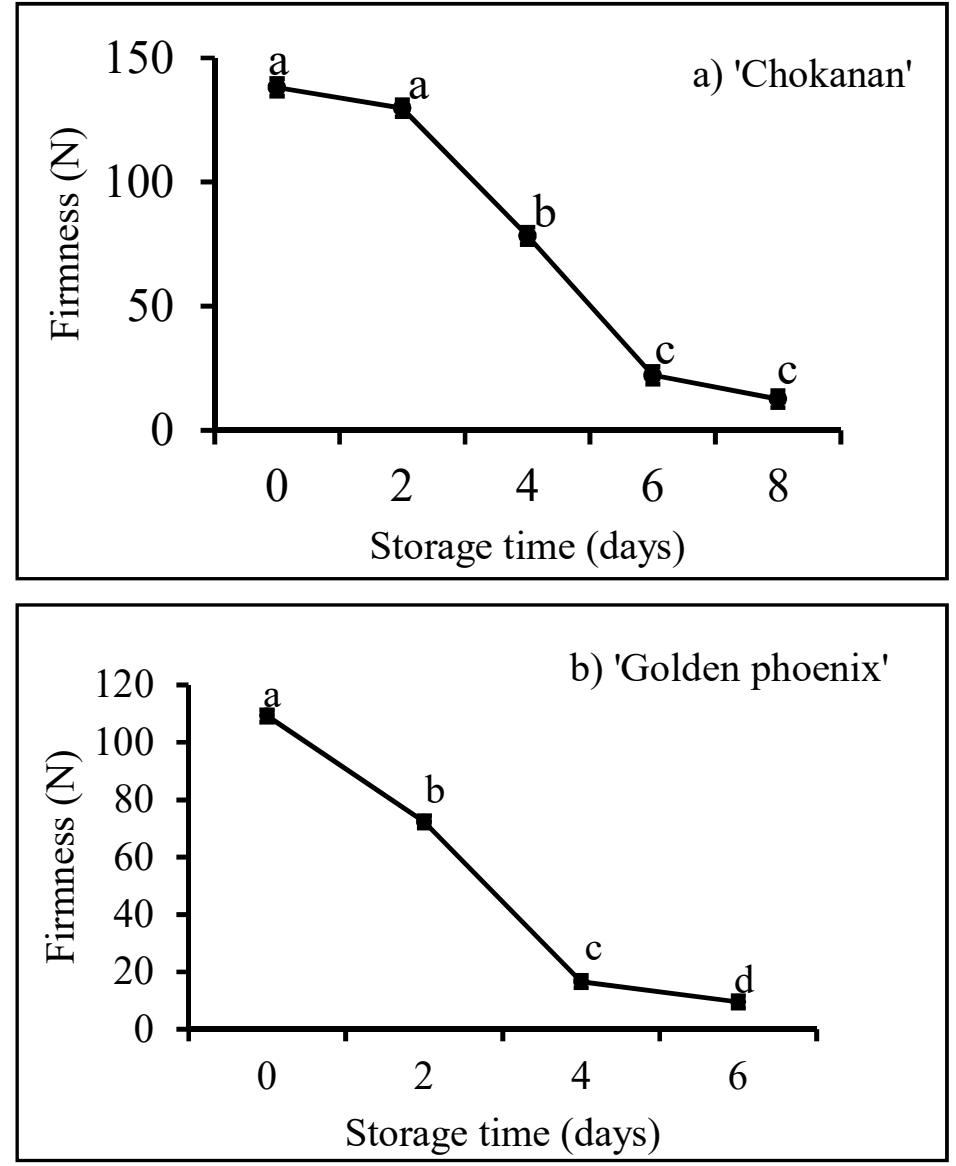

290

Figure 3. Firmness of a) 'Chokanan' b) 'Golden phoenix' and c) 'Water lily' mango varieties Different letters indicate significant difference between storage times at $\mathrm{p}<0.05$ for each mango 


\subsubsection{Titratable acidity (TA) and soluble solids content (SSC)}

299

300

301

302

303

304

In general, SSC value increased while TA declined during storage regardless of the variety. Changes in SSC and TA observed are shown in Fig. 4. The initial SSC content for 'Chokanan' was $6.83 \%$ and it peaked $(\mathrm{p}<0.05)$ at $16.80 \%$ on the 8 th day of storage (Fig. $4 a)$ when the fruit was ripe (as depicted by the peel coloration; Fig. 2). SSC did not present much variation between storage days. TA decreased from $1.05 \%$ on day zero to $0.26 \%$ on the 8 th day of ripening. SSC value in 'Golden phoenix', which started at $7.18 \%$ was maintained with significant differences between the days of ripening (Fig. 4b). However, on the 6th day of storage the highest SSC value (20.30\%) was observed. A decrease in TA was recorded for 'Golden phoenix' from $0.69 \%$ to $0.19 \%$, which was not statistically different $(p>0.05)$ between the 2 nd and 4 th day of storage. In 'Water lily', a significant increase in SSC value beginning on day four was recorded. The value was maintained until the end of the storage (Fig. 4c). However, changes in SSC were negligible between day four and six. While SSC increased, TA decreased from $0.34 \%$ to $0.12 \%$ after six days of ripening.

(1)

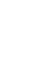

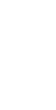



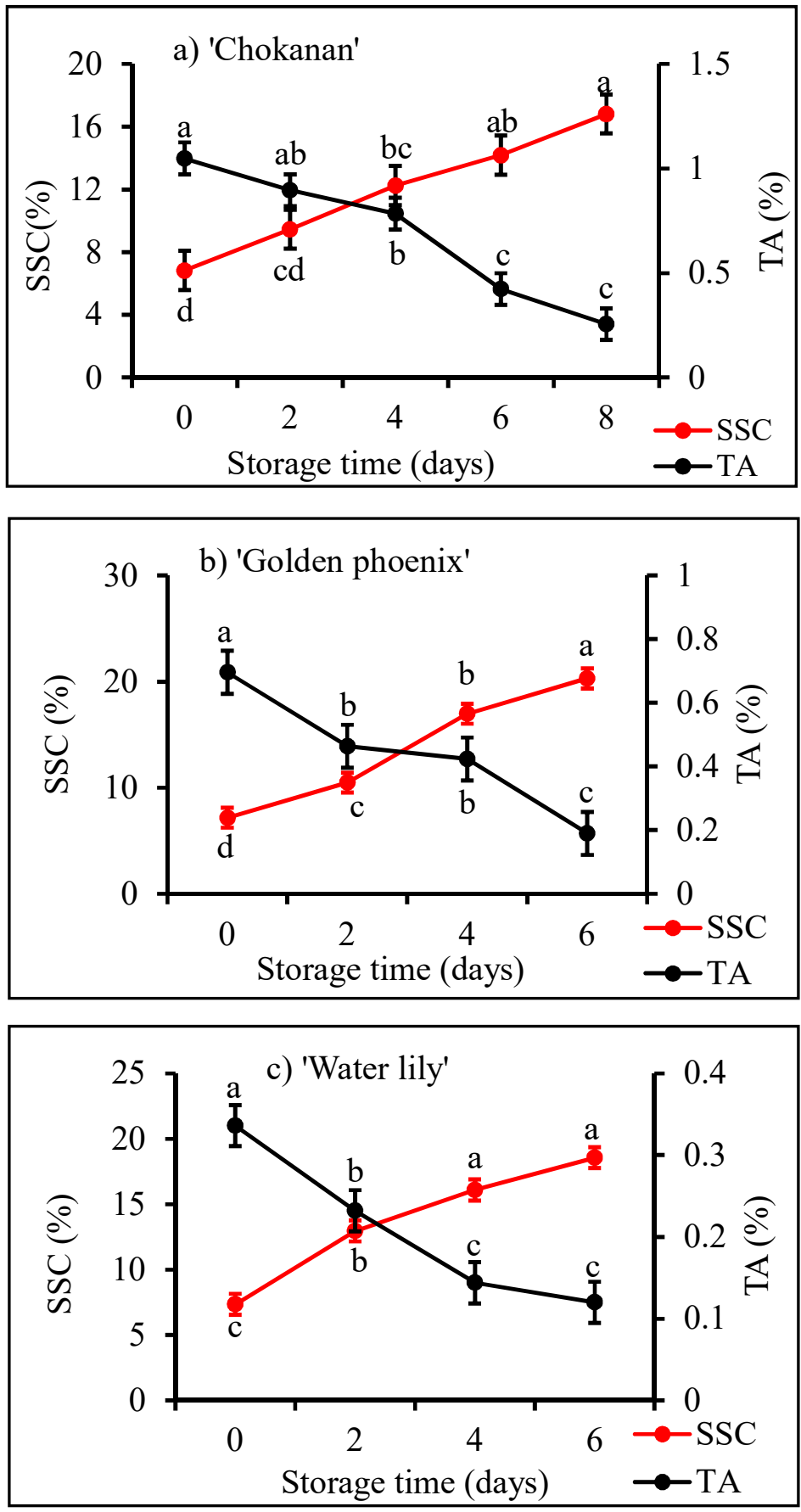

Figure 4. Titratable acidity and soluble solid concentration of (a) 'Chokanan' (b) 'Golden phoenix' and (c) 'Water lily') mango varieties during storage. Note: Vertical bars indicate standard error of mean of four replicates per variety. Different letters indicate significant difference between storage times at $\mathrm{p}<0.05$ for each mango variety. SSC, soluble solid concentration; TA, titratable acidity 


\subsubsection{Respiration and ethylene production}

A typical climacteric pattern of respiration and ethylene production was observed in all mango varieties during ripening (Fig. 5). In 'Chokanan', a respiratory climacteric was apparent on the 4th day of storage and peaked at $579.40 \mathrm{nmol} \mathrm{kg}^{-1} \mathrm{~s}^{-1}$ on the 6th day (Fig. 5a) when fruit exhibited a more yellow peel color. Ethylene production also peaked on the 6th day with a maximum value of $0.010 \mathrm{nmol} \mathrm{kg}^{-1} \mathrm{~s}^{-1}$ and decreased afterwards (Fig. 5a). Respiration rate of 'Golden phoenix' was $279.10 \mathrm{nmol} \mathrm{kg} \mathrm{s}^{-1}$ on day zero reaching a climacteric maximum of $939.3 \mathrm{nmol} \mathrm{kg}^{-1} \mathrm{~s}^{-1}$ on the 4th day. This was followed by a decrease to $797.70 \mathrm{nmol} \mathrm{kg}^{-1} \mathrm{~s}^{-1}$ on the sixth day (Fig. 5b). Maximum production of ethylene was observed in fruit from the 4th day $\left(0.011 \mathrm{nmol} \mathrm{kg}{ }^{-1} \mathrm{~s}^{-1}\right)$ (Fig. 5b). In 'Water lily' a respiratory climacteric was apparent after two days in storage and peaked at $1161.40 \mathrm{nmol} \mathrm{kg}^{-1} \mathrm{~s}^{-1}$ on the 4th day (Fig. 5c). Ethylene production also peaked on the 4th day of storage with a maximum value of $0.013 \mathrm{nmol} \mathrm{kg}^{-1} \mathrm{~s}^{-1}$ (Fig. 5c). At that moment the production peaks, it declined until the end of the storage.

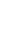




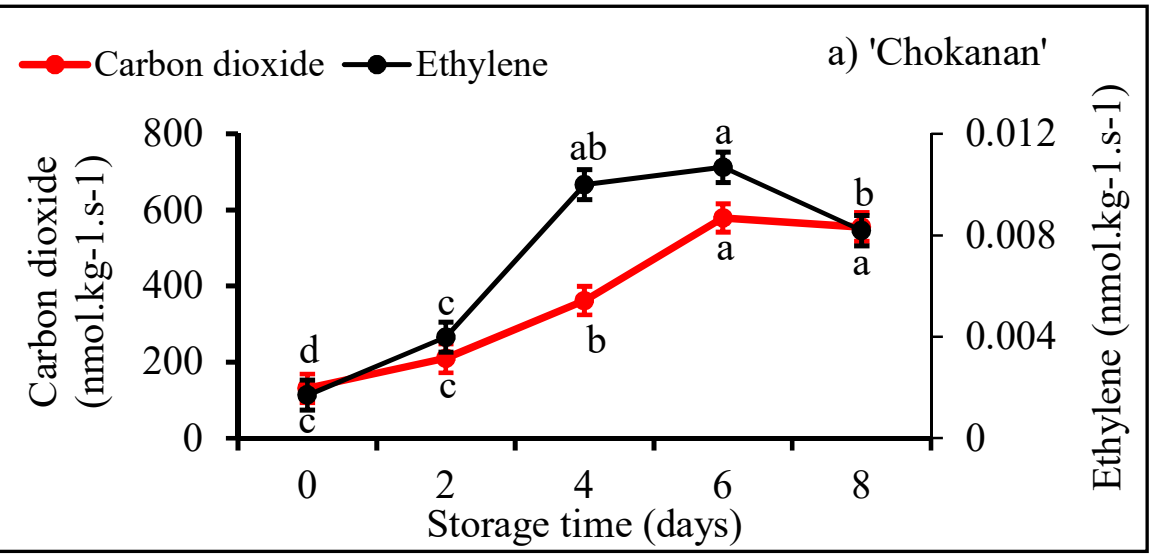

392
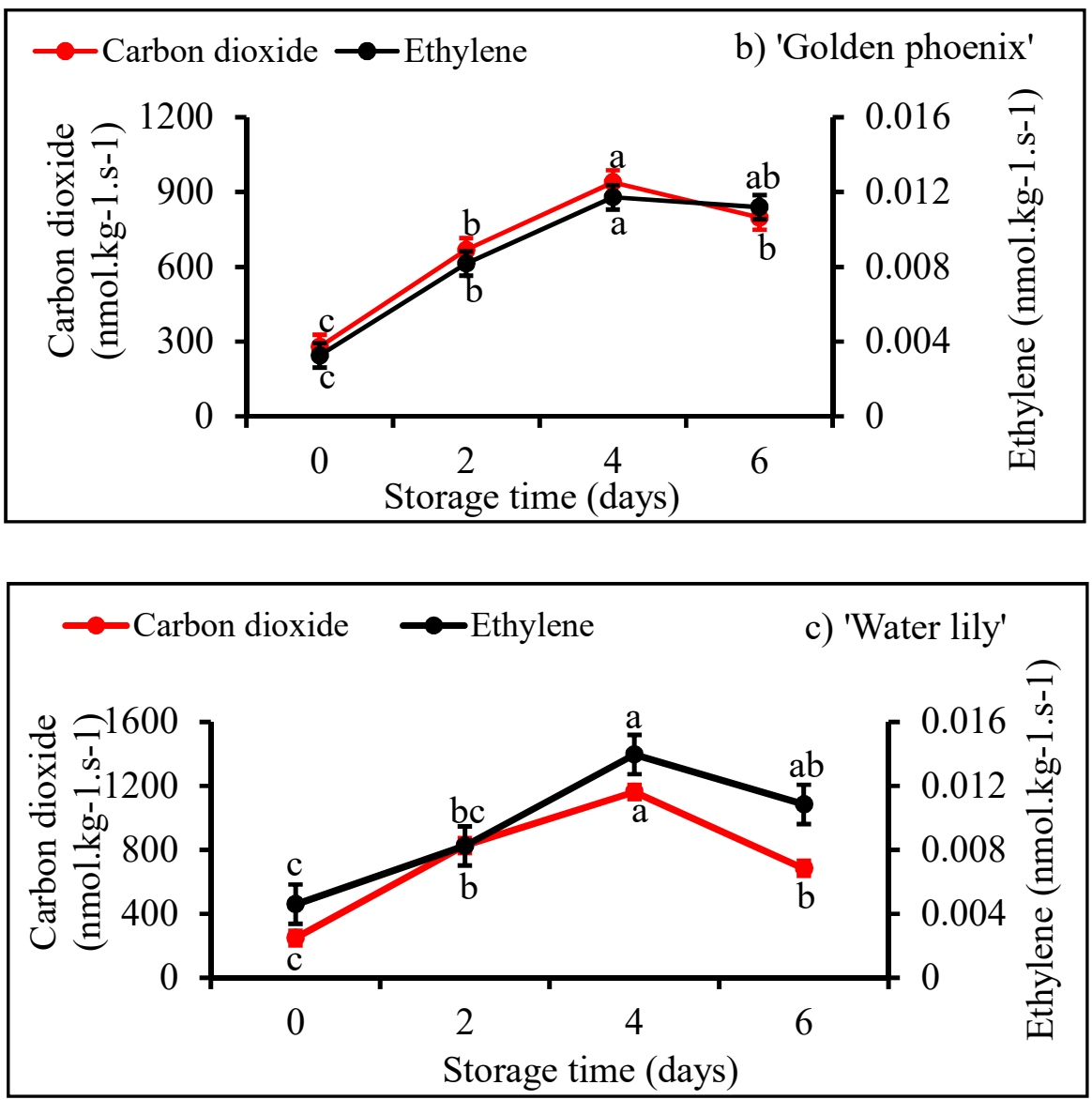

Figure 5: Respiratory pattern and ethylene production of (a) 'Chokanan' (b) 'Golden phoenix' and (c) 'Water lily') mango varieties during storage. Note: Vertical bars indicate standard error of mean of four replicates per variety. Different letters indicate significant difference between storage times at $\mathrm{P}<0.05$ for each mango variety 


\subsection{Multivariate analysis of postharvest quality parameters}

Pearson's correlation coefficient (r) was employed to explore the relationship between the postharvest quality parameters during fruit ripening. Results are presented in Table 2. Respiration showed a significant $(\mathrm{p}<0.05)$ positive correlation between ethylene $(\mathrm{r}=0.84)$ and $\operatorname{SSC}(r=0.67)$. Ethylene also showed a significant positive correlation with $\operatorname{SSC}(r=0.67, p=$ $0.012)$ and a negative correlation with firmness $(r=-0.81, \mathrm{p}<0.01)$ and TA $(-0.60, \mathrm{p}=0.029)$ respectively. Firmness was positively correlated with hue $(r=0.59, \mathrm{p}=0.035)$ and TA $(r=0.86$, $\mathrm{p}<0.01)$ while a negative correlation was shown for $\mathrm{b}^{*}$ value $(\mathrm{r}=-0.76, \mathrm{p}<0.01)$ and SSC $(\mathrm{r}=$ $-0.86, \mathrm{p}<0.01)$.

Furthermore, to obtain a broader view on the postharvest quality changes that occurred during fruit ripening, the whole data set was subjected to principal component analysis (PCA) using the correlation matrix. The first principal component (F1) explained up to $62.18 \%$ of total variance and PC2 explained $21.59 \%$, totaling $83.77 \%$. The rest of the components varied to a less extent with $16.23 \%$ of total variance. The samples of all varieties were well separated on the PCA biplot (Fig. 6). Samples were separated along the first principal component (F1) based on firmness, SSC, TA, b* value, ethylene and respiration rate. The second $\mathrm{PC}$ classified the samples related to their external coloration (hue, $\mathrm{L}^{*}$ and $\mathrm{a}^{*}$ values). The positive contribution on F1 dimension is due to high TA and firmness, whereas the negative contribution is due mainly to high SSC, respiration and ethylene rate. Separation of samples according to their ripening state was achieved on F1 dimension, with unripe fruit located at the right hand side and ripe fruit on the left hand side. In other words, unripe fruit have a higher firmness and TA while ripe fruit have higher SSC. The contribution of $b^{*}$ value tells us that there is a great variability between unripe and ripe fruit of the studied mango varieties based on their yellowness although this is 
more conspicuous in 'Chokanan' variety (Fig. 2). On the other hand, F2 dimension showed separation related to the variety effect, with 'Chokanan' samples at the top (increased L* and $\left.a^{*}\right)$ and the other varieties on the lower region (high hue values). However, no clear demarcation was achieved for 'Waterlily' and' Golden phoenix' varieties. This could be due to a lesser variability of the color coordinates (hue, $\mathrm{L}^{*}$ and $\mathrm{a}^{*}$ ) on the $\mathrm{F} 2$ dimension between these varieties. The green coloration retained by these varieties ('Waterlily' and 'Golden phoenix') upon 451 ripening supports this possibility (Fig. 2). More positive scores along F2 dimension for 452 'Chokanan' on the $8^{\text {th }}$ day of storage could be as a result of further accumulation of pigmentation 453 yielding more yellow coloration as ripening progresses.

455 Table 2: Correlation matrix among postharvest quality variables

\begin{tabular}{|c|c|c|c|c|c|c|c|c|c|}
\hline Variables & Respiration & Ethylene & Firmness & Hue & $a^{*}$ & $\mathrm{~L}^{*}$ & $\mathrm{~b}^{*}$ & TA & SSC \\
\hline Respiration & 1 & $0.84^{*}$ & $-0.81 *$ & -0.26 & 0.17 & 0.19 & 0.52 & $-0.60 *$ & $0.67 *$ \\
\hline Ethylene & & 1 & $-0.79 *$ & -0.47 & 0.30 & 0.38 & $0.74 *$ & $-0.59 *$ & $0.67^{*}$ \\
\hline Firmness & & & 1 & $0.59 *$ & -0.49 & -0.37 & $-0.76^{*}$ & $0.86^{*}$ & $-0.86^{*}$ \\
\hline Hue & & & & 1 & $-0.96 *$ & $-0.90^{*}$ & -0.51 & 0.34 & $-0.69 *$ \\
\hline$a^{*}$ & & & & & 1 & $0.83^{*}$ & 0.31 & -0.26 & $0.58^{*}$ \\
\hline $\mathrm{L}^{*}$ & & & & & & 1 & 0.39 & -0.10 & $0.57^{*}$ \\
\hline$b^{*}$ & & & & & & & 1 & $-0.62 *$ & $0.71^{*}$ \\
\hline TA & & & & & & & & 1 & $-0.64 *$ \\
\hline $\mathrm{SSC}$ & & & & & & & & & 1 \\
\hline
\end{tabular}

458

459

460

461

462

463 


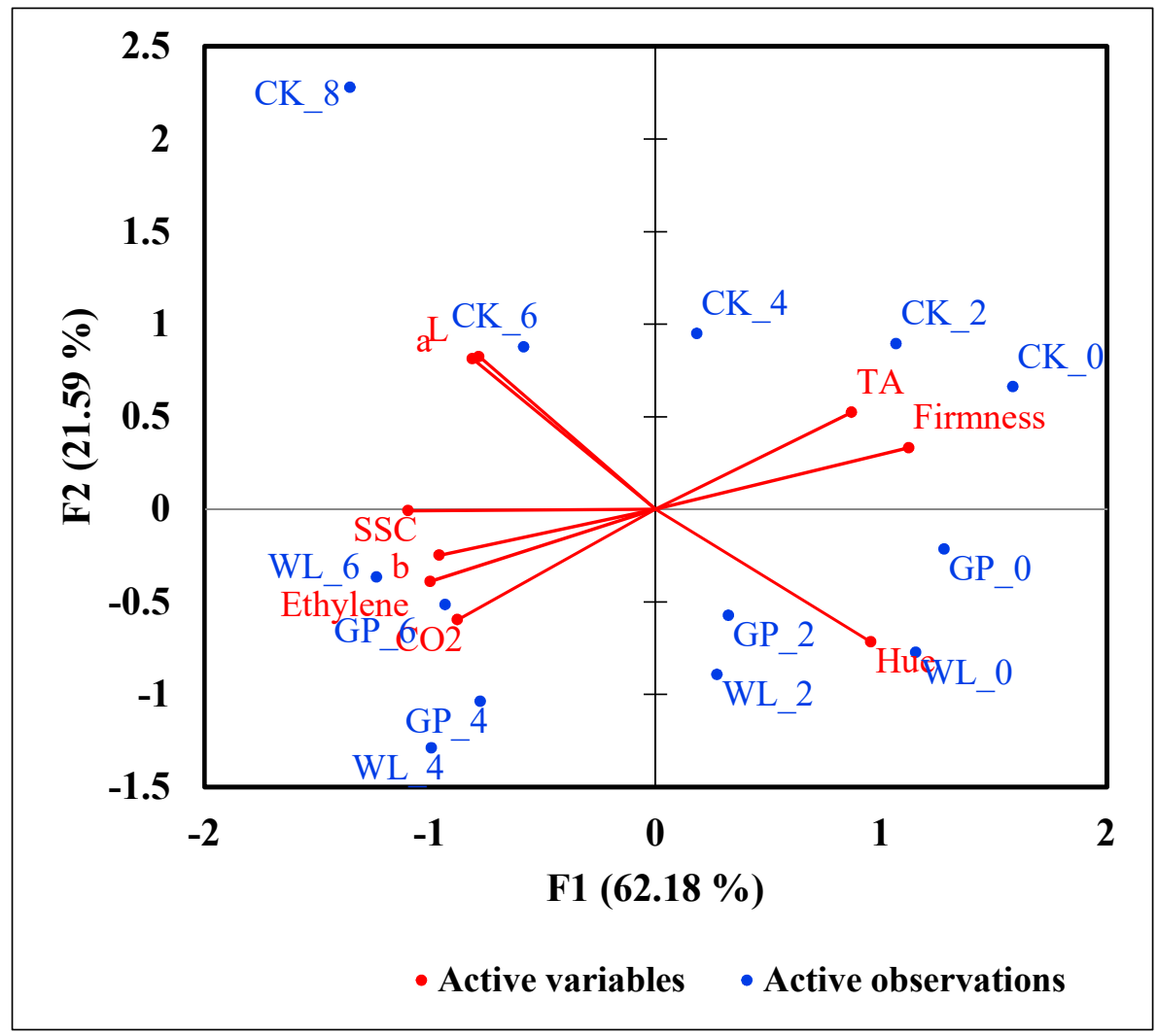

478

479

480

Figure 6. PCA biplot of the postharvest quality attributes in the three mango varieties 'Chokanan'

481 (CK), 'Golden phoenix' (GP) and Waterlily (WL) on 0th day (0), 2nd day (2), 4th day (4), 6th

482

483 day (6) and 8th (8). (L, $\mathrm{L}^{*}$ value; $\mathrm{a}, \mathrm{a}^{*}$ value; $\mathrm{b}, \mathrm{b}^{*}$ value; $\mathrm{CO}_{2}$, carbon dioxide; SSC, soluble 484 


\section{Discussion}

486

487

488

489

490

491

492

493

494

495

496

497

498

499

500

501

502

503

504

505

506

\subsection{Changes in postharvest qualities}

\subsubsection{Weight loss}

Weight loss is an aspect that determines the storage life and quality of fruit. Harvested fruit continue to respire and lose water to the environment. In mango, water loss through the stomata and lenticels seems to be the possible reason for physiological weight loss during storage (Brecht and Yahia, 2009). The results from this study are in line with the findings obtained from 'Dashehari' mango (Gupta and Jain, 2012) and other climacteric fruit such as papaya (Ong et al., 2013) at ambient storage. However, the variability among species, varieties, ripening stage and storage conditions could be possible factors explaining the differences (Kader, 2002).

\subsubsection{Peel color changes}

A change in peel color is mainly caused by the degradation of chlorophyll and accumulation of pigments such as carotenoid, xanthophyll and lycopene (Ornelas-Paz et al., 2008). The peel color showed a reduction in hue values and increase in $\mathrm{L}^{*}$ value, characterizing the loss of the green color during fruit ripening. However, our results show that peel color is not a stand-alone indicator but rather more useful when combined with other quality parameters throughout ripening period. The results from this study show similar trends to those observed in other mango varieties (Ibarra-Garza et al., 2015; Palafox-Carlos et al., 2015).

\subsubsection{Loss of fruit firmness}

'Chokanan' variety has been reported to be a firm variety in comparison with other varieties under study (Jarimopas and Kitthawee, 2007; Vásquez-Caicedo et al., 2002). This is in agreement with our observations for 'Chokanan' variety having a longer storage period. 
Decreased fruit firmness has been reported in other mango varieties (Jha et al., 2013; IbarraGarza et al., 2015; Palafox-Carlos et al., 2015). Flesh firmness is of great concern in mango as it plays an integral role in shelf life, pathogen resistance, transportation and storage of the fresh produce. Loss of flesh firmness has been reported to be associated with the cell wall modification and starch hydrolysis (Muda et al., 1995). The best organoleptic quality of mango fruit is when they are soft with a pulp firmness between $4.5 \mathrm{~N}$ and 26. $7 \mathrm{~N}$ (Nassur et al., 2015).

\subsubsection{Titratable acidity and soluble solids concentration}

TA and SSC play an important role in both fresh and processing markets of table fruit. The patterns of TA and SSC observed in this study have been similarly reported for other mango varieties such as 'Ataulfo' (Palafox-Carlos et al., 2015), 'Haden' (Nassur et al., 2015) and 'Keitt' (Padda et al., 2011). However, the different acidity values obtained in the respective studies reflects variations exist among various mango varieties (Yahia, 2011). Decline in acidity is attributed to their utilization as substrates for respiration and conversion to sugars as ripening progresses (Espitia et al., 2012). SSC values for 'Chokanan' variety were similar to those reported by Bejo and Kamarudin, (2011) from the same variety and geographical region. Overall, studies on other mango varieties (Nassur et al., 2015; Ibarra-Garza et al., 2015; Padda et al., 2011; Palafox-Carlos et al., 2015) corroborate with the findings generated in this studies. The SSC of all the ripe mango varieties in this study fitted well with the 10-20\% SSC requirement for ripe mangoes (Mitcham, 2012; Yahia, 2011).

\subsubsection{Respiration and ethylene production}

Climacteric fruits such as mango are characterized by an increase in respiration rate and ethylene production. Based on the results, it can be inferred that the climacteric rise in mango fruit 
occurred when it was considerably ripe. Similar patterns have been reported for other mango varieties such as 'Ataulfo' (Palafox-Carlos et al., 2015) and 'Cogshall' (Nordey et al., 2016). In contrast, 'Amrapali' and 'Dasheri' mangoes did not follow a climacteric pattern (Reddy and Srivastava, 1999). Similar ethylene production rates recorded in this study were reported for other mango varieties such as 'Carabao' (Cua and Lizada, 1990), 'Kesington pride' (Lalel et al., 2003) and 'Ataulfo' (Palafox-Carlos et al., 2015). As observed by these authors, the outburst of ethylene may precede, coincide or lag behind the respiratory peak during mango ripening. The comparison of the respiration profiles and the ethylene production for the three mango varieties revealed that the two physiological processes occurred in a similar way.

Furthermore, the mangoes investigated in this study were comparable to the globally traded mango varieties (Appendix Table 1). The tropical mango varieties under study did not differ greatly from the commercial mangoes reported so far in terms of their postharvest quality parameters including pulp firmness, soluble solids and titratable acidity. On the other hand, the peel color of 'Golden phoenix' and 'Water lily' varieties tended to be higher, characterizing by their green fruit coloration (Fig. 2) upon ripening compared to the other varieties. Since peel color is one of the most important visual attributes in mango that drives marketability and consumption (Jha et al., 2013; Nassur et al., 2015), this quality of not attaining a full yellow coloration may influence the consumer acceptance of 'Golden phoenix' and 'Water lily' mangoes in the international market (Jha et al., 2013; Nassur et al., 2015). Regarding firmness and SSC, the Southeastern mangoes fitted well at $4.5-26 \mathrm{~N}$ pulp firmness (Nassur et al., 2015) and $10-20 \%$ SSC (Mitcham, 2012; Yahia, 2011) requirement for ripe mangoes. Even though 'Golden phoenix' and 'Water lily' mangoes show green coloration upon ripening, utilization of these varieties in the pulping industry for mango purée and juices may be a good option because 
of the soluble solid concentration and acidity level (Nambi et al., 2015; Vásquez-Caicedo et al., 2002). Taken together, the results of this study offer new insights to uncover the potential of the investigated mango varieties to become commercially marketable fruits.

\subsection{Multivariate studies}

Pearson's correlation coefficient was employed to explore the relationship between the postharvest quality parameters during fruit ripening. The positive relationship between SSC and $\mathrm{b}^{*}$ value can be explained by the observation that as ethylene, respiration and SSC increases during ripening, the fruit becomes less acidic and firm. The negative correlation between hue and the other color coordinates ( $\mathrm{b}^{*}$ and $\mathrm{L}^{*}$ values) is expected because as a mango fruit ripens, these values increases with pigment accumulation leading to a reduced hue value (fruit becoming brighter and more yellow). Correlation of some postharvest parameters observed in this study are in line with studies in mango (Nambi et al., 2015) and tomato (Aoun et al., 2013). Hue was not significantly correlated with respiration and ethylene, which agree with the observation by Ketsa et al., (1999) who found that 'Tongdum' mangoes, which remained green upon ripening had high ethylene production compared with 'Nam Dok Mai' mangoes, which turn completely yellow. Similar discrimination based on fruit ripening stages as observed in this study has been reported in other mango varieties (Nambi et al., 2015; Padda et al., 2011) and banana (Valérie Passo Tsamo et al., 2014). As the fruit ripened, there was a shift from right to left along F1 (Fig. 6) with increase in SSC, yellowness ( $b^{*}$ value), ethylene and respiration rate. In this study, decrease in acidity and firmness in unripe fruit, was also characterized by a shift from right to left, reflecting the ripening process in the mango varieties. The two principal components played an important role in explaining the total variation of the external appearance in this study since color coordinates (hue, $\mathrm{L}^{*}, \mathrm{~b}^{*}$ and $\mathrm{a}^{*}$ values) were distributed over the PCA biplot. The lack of 
separation between 'Golden phoenix' and 'Water lily' mangoes on the F2 dimension could be due to a lesser variability of the changes in color coordinates (hue, $\mathrm{L}^{*}$ and $\mathrm{a}^{*}$ values) between 'Golden phoenix' and 'Water lily' varieties as ripening progressed over the storage time. There is a huge variability of postharvest attributes among mango varieties. For this reason, a common classification of postharvest qualities is not suitable for all mango varieties (Nambi et al., 2016). Multivariate comparisons clearly indicated the correlation between the physicochemical parameters and their relationship in different mango fruit varieties during the ripening period. The present postharvest studies to assess the phenotypic variabilities in the mango fruit varieties would be useful indicators for postharvest quality determination.

\section{Conclusion}

This study showed that variety and ripening period had an impact on the postharvest qualities on mango fruit. Considering the high genetic variability of the mango varieties, additional investigations at the biochemical and molecular levels are recommended to provide a more complete picture of what occurs at ripening. Besides understanding ripening behavior, it would be beneficial to integrate the results of this study with additional investigations that also take into consideration different harvesting times, location and postharvest storage conditions. Such information will provide an insight into the development of postharvest management strategies towards mango fruit quality improvement and open new marketing opportunities to the farmers and the local industry. Multivariate analysis has shown to be a valuable tool in making decisions and view variable/variety interrelations, thus facilitating mango selection and utilization strategy. Consumer perception for the fruit is an important factor that influences the marketability of fruits such as mango. As such, further investigation on these mango varieties aiming at the evaluation of their sensory properties will provide valuable information which could be used by growers, 
plant breeders, exporters and marketing agents to facilitate increased utilization and export of varieties that would be acceptable by consumers globally. Nevertheless, the information provided in this study would likely to open up promising possibilities in the world market trade for Southeast Asian mangoes which are locally common but globally rare.

\section{Acknowledgements}

This work was supported by the CFF-UNMC Doctoral Training Partnership under the FoodPlus program [Food P1-016]. The authors wish to thank Dr. Ajit Singh for his invaluable help in the statistical analysis.

Declarations of interest: none

\section{References}

Abu Bakar, M.F.A., Fry, J., 2013. A review on underutilized indigenous 'Bambangan' (Mangifera pajang) fruit as a potential novel source for functional food and medicine. Journal of Medicinal Plant Research 7, 3292-3297.

Ali, A., Hei, G.K., Keat, Y.W., 2016. Efficacy of ginger oil and extract combined with gum arabic on anthracnose and quality of papaya fruit during cold storage. Journal of Food Science and Technology 53, 1435-1444. doi:10.1007/s13197-015-2124-5

Aoun, A.B., Lechiheb, B., Benyahya, L., Ferchichi, A., 2013. Evaluation of fruit quality traits of traditional varieties of tomato (Solanum lycopersicum) grown in Tunisia. African Journal of Food Science 7, 350-354. doi:10.5897/ajfs2013.1067

Bally, I.S.E., 2011. Advances in research and development of mango industry. Revista Brasileira de Fruticultura 33, 57-63. doi:10.1590/s0100-29452011000500008 
Banks, N., Cleland, D., Cameron, A., Beaudry, R., Kader, A.A, 1995. Proposal for rationalized system of units for post-harvest research in gas exchange. Hortscience 30, 1129-1131.

Barry, C.S, Giovannoni, J.J., 2007. Ethylene and fruit ripening. Journal of Plant Growth Regulation 26, 143-159.

Bejo, S.K., Kamaruddin, S., 2014. 'Chokanan' mango sweetness determination using nondestructive image processing technique. Australian Journal of Crop Science 8, 475-480.

Brecht, J.K., Yahia, E.M., 2009. Postharvest Physiology, in: Richard, L. (Ed) The mango botany, production and uses. CABI, Wallingford, U.K, pp. 484-528.

Carrillo-Lopez, A., Ramirez-Bustamante, F., Valdez-Torres, J.B., Rojas-Villegas, R., Yahia, E.M., 2000. Ripening and quality changes in mango fruit as affected by coating with an edible film. Journal of Food Quality 23, 479-486. doi:10.1111/j.1745-4557.2000.tb00573.x

Cua, A.U., Lizada, M.C.C., 1990. Ethylene production in the Carabao mango (Mangifera Indica L.) fruit during maturation and ripening. Acta Horticulturae 169-180. doi:10.17660/actahortic.1990.269.22

Deshpande, A., Anamika, K., Jha, V., Chidley, H., Oak, P., Kadoo, N., Pujari, K., Giri, A., Gupta, V., 2017. Transcriptional transitions in Alphonso mango (Mangifera indica L.) during fruit development and ripening explain its distinct aroma and shelf life characteristics. Scientific Reports 7, 8711. doi:10.1038/s41598-017-08499-5.

Espitia, P.J.P., Soares, N.F.F., Botti, L.C.M., Melo, N.R., Pereira, O.L., Silva, W.A., 2012. Assessment of the efficiency of essential oils in the preservation of postharvest papaya in an 
antimicrobial packaging system. Brazilian Journal of Food Technology 15, 333-342. doi:10.1590/s1981-67232012005000027

FAMA, Federal Agricultural and Marketing Authority, 2017. Grading standards and specification of fruits and vegetables http://www.fama.gov.my/documents/10157/af9f2d40c116-4a3e-8c8ccc1c897bb039 (accessed 6th May, 2017).

FAOSTAT, Food and Agriculture Organization of the United Nations: Statistics Division, World mango production in 2016. http://www.fao.org/faostat/en/\#data/QC (accessed 20th November, 2017).

Galán Saúco, V., 2015. Current situation and future prospects of worldwide mango production and market. Acta Horticulturae 69-84. doi:10.17660/actahortic.2015.1066.7

Gupta, N., Jain, S.K., 2014. Storage behavior of mango as affected by post-harvest application of plant extracts and storage conditions. Journal of Food Science and Technology 51, 24992507. doi:10.1007/s13197-012-0774-0

Ibarra-Garza, I.P., Ramos-Parra, P.A., Hernández-Brenes, C., Jacobo-Velázquez, D.A., 2015. Effects of postharvest ripening on the nutraceutical and physicochemical properties of mango (Mangifera indica L. cv 'Keitt'). Postharvest Biology and Technology 103, 45-54. doi:10.1016/j.postharvbio.2015.02.014

Jarimopas, B., Kitthawee, U., 2007. Firmness properties of mangoes. International Journal of Food Properties 10, 899-909. doi:10.1080/10942910701221731 
658

659

660

661

662

663

664

665

666

667

668

669

670

671

672

673

674

675

676

677

Jha, S.N., Jaiswal, P., Narsaiah, K., Kaur, P.P., Singh, A.K., Kumar, R., 2013. Textural properties of mango cultivars during ripening. Journal of Food Science and Technology 50, 1047-1057. doi:10.1007/s13197-011-0431-Z

Kader, A.A., 2002. Postharvest biology and technology: an overview, in: Kader, A.A. (Ed.) Postharvest Technology of Horticultural Crops. University of California, Agriculture and Natural Resources, Oakland, CA, pp. 39-47

Ketsa, S., Phakawatmongkol, W., Subhadrabhandhu, S., 1999. Peel enzymatic activity and colour changes in ripening mango fruit. Journal of Plant Physiology 154, 363-366. doi:10.1016/s0176-1617(99)80181-3

Khaliq, G., Mohamed, M.T.M., Ali, A., Ding, P., Ghazali, H.M., 2015. Effect of gum arabic coating combined with calcium chloride on physico-chemical and qualitative properties of mango (Mangifera indica L.) fruit during low temperature storage. Scientia Horticulturae 190, 187-194. doi:10.1016/j.scienta.2015.04.020

Kuhn, D.N., Bally, I.S.E., Dillon, N.L., Innes, D., Groh, A.M., Rahaman, J., Ophir, R., Cohen, Y., Sherman, A., 2017. Genetic map of mango: A tool for mango breeding. Frontiers in Plant Science 8, 577. doi:10.3389/fpls.2017.00577

Lalel, H.J.D., Singh, Z., Tan, S.C., Agustí, M., 2003. Maturity stage at harvest affects fruit ripening, quality and biosynthesis of aroma volatile compounds in 'Kensington Pride' mango. The Journal of Horticultural Science and Biotechnology 78, 225-233. doi:10.1080/14620316.2003.11511610 
Lauricella, M., Emanuele, S., Calvaruso, G., Giuliano, M., D’Anneo, A., 2017. Multifaceted health benefits of Mangifera indica L. (mango): The inestimable value of orchards recently planted in Sicilian rural areas. Nutrients 9, 525. doi:10.3390/nu9050525

Mansor, A., Mahmod, O., Nazari, A., 2014. Fuzzy ripening mango index using RGB colour sensor model. Research Journal of Art Science \& Commerce 5, 1-9

Mitcham, B., 2012. Mango ripening [PowerPoint slides]. Retrieved from http://ucce.ucdavis.edu/files/datastore/234-2168.pdf

Muda, P., Seymour, G.A., Errington, N., Tucker, G.A., 1995. Compositional changes in cell wall polymers during mango fruit ripening. Carbohydrate Polymers 26, 255-260. doi:10.1016/0144-8617(95)00028-6

MOA, Ministry of Agriculture and Agro based Industry, Malaysia, 2016. Mango. http://www.moa.gov.my/buah-buahan (accessed 15th December, 2017).

Nambi, V., Thangavel, K., Shahir, S., Chandrasekar, V., 2016. Color Kinetics During Ripening of Indian Mangoes. International Journal of Food Properties 19, 2147-2155. doi:10.1080/10942912.2015.1089281

Nambi, V.E., Thangavel, K., Jesudas, D.M., 2015. Scientific classification of ripening period and development of color grade chart for Indian mangoes (Mangifera indica L.) using multivariate cluster analysis. Scientia Horticulturae 193, 90-98. doi:10.1016/j.scienta.2015.05.031.

Nassur, R.C., González-Moscoso, S., Crisosto, G.M., Lima, L.C., Vilas Boas, E.V., Crisosto, C.H., 2015. Describing quality and sensory attributes of 3 mango (Mangifera indica L.) 
cultivars at 3 ripeness stages based on firmness. Journal of Food Science 80, S2055-S2063. doi:10.1111/1750-3841.12989.

Nordey, T., Léchaudel, M., Génard, M., Joas, J., 2016. Factors affecting ethylene and carbon dioxide concentrations during ripening: Incidence on final dry matter, total soluble solids content and acidity of mango fruit. Journal of Plant Physiology 196-197, 70-78. doi:10.1016/j.jplph.2016.03.008

Ong, M.K., Forney, C.F., Alderson, P.G., Ali, A., 2013. Postharvest profile of a Solo variety 'Frangi' during ripening at ambient temperature. Scientia Horticulturae 160, 12-19. doi:10.1016/j.scienta.2013.05.026.

Ornelas-Paz, J., Yahia, E.M., Gardea, A.A., 2008. Changes in external and internal color during postharvest ripening of 'Manila' and 'Ataulfo' mango fruit and relationship with carotenoid content determined by liquid chromatography-APcI+-time-of-flight mass spectrometry. Postharvest Biology and Technology 50, 145-152. doi:10.1016/j.postharvbio.2008.05.001

Padda, M.S., do Amarante, C.V., Garcia, R.M., Slaughter, D.C., Mitcham, E.J., 2011. Methods to analyse physico-chemical changes during mango ripening: A multivariate approach. Postharvest Biology and Technology 62, 267-274. doi:10.1016/j.postharvbio.2011.06.002.

Palafox-Carlos, H., Yahia, E.M., Islas-Osuna, M., Gutierrez-Martinez, P., Robles-Sánchez, M., González-Aguilar, G., 2012. Effect of ripeness stage of mango fruit (Mangifera indica L., cv. 'Ataulfo') on physiological parameters and antioxidant activity. Scientia Horticulturae 135, 7-13. doi:10.1016/j.scienta.2011.11.027.

Reddy, Y.T.N., Srivastava, G.C., 1999. Ethylene biosynthesis and respiration in mango fruit during ripening. Indian Journal of Plant Physiology 4, 32-35. 
Singh, N., Mahato, A., Jayaswal, P., Singh, A., Singh, S., Singh, N., Rai, V., Mithra, A., Gaikwad, K., Sharma, N., Lal, S., Srivastava, M., Prakash, J., Kalidindi, U., Singh, S., Singh, A., Khan, K., Mishra, R., Rajan, S., Bajpai, A., Sandhya, B., Nischita, P., Ravishankar, K., Dinesh, M., Kumar, N., Jaiswal, S., Iquebal, M., Kumar, D., Rai, A., Sharma, T., 2016. Origin, diversity and genome sequence of mango (Mangifera indica L.). Indian Journal of History of Science 51. doi:10.16943/ijhs/2016/v51i2.2/48449.

Srivastava, S., Singh, R.K., Pathak, G., Goel, R., Asif, M.H., Sane, A.P., Sane, V.A., 2016. Comparative transcriptome analysis of unripe and mid-ripe fruit of Mangifera indica (var. 'Dashehari') unravels ripening associated genes. Scientific Reports 6, 32557. doi:10.1038/srep32557.

Valérie Passo Tsamo, C., Andre, C., Ritter, C., Tomekpe, K., Ngoh Newilah, G., Rogez, H., Larondelle, Y., 2014. Characterization of Musa sp. fruit and plantain banana ripening stages according to their physicochemical attributes. Journal of Agricultural and Food Chemistry 62, 8705-8715. doi:10.1021/jf5021939

Vásquez-Caicedo, A., Neidhart, S., Pathomrungsiyounggul, P., Wiriyacharee, P., Chattrakul, A., Sruamsiri, P., Manochai, P., Bangerth, F., Carle, R., 2002. Physical, chemical and sensory properties of nine Thai mango cultivars and evaluation of their technological and nutritional potential, in: International symposium sustaining food security and managing natural resources in Southeast Asia - Challenges for the $21^{\text {st }}$ century.

Yahia, E.M., 2011. Mango (Mangifera indica L.), in: Yahia, E.M, Postharvest biology and technology of tropical and subtropical fruit: cocona to mango. Woodhead Publishing Limited, pp. 492B-586 
Zakaria, A., Shakaff, A., Masnan, M., Saad, F., Adom, A., Ahmad, M., Jaafar, M., Abdullah, A., Kamarudin, L., 2012. Improved maturity and ripeness classifications of Magnifera Indica cv. 'Harumanis' mangoes through sensor fusion of an electronic nose and acoustic sensor. Sensors 12, 6023-6048. doi:10.3390/s120506023.

Zerbini, P.E., Vanoli, M., Rizzolo, A., Grassi, M., Pimentel, R.M., Spinelli, L., Torricelli, A., 2015. Optical properties, ethylene production and softening in mango fruit. Postharvest Biology and Technology 101, 58-65. doi:10.1016/j.postharvbio.2014.11.008.

Appendix Table 1: Comparison of postharvest quality attributes between Southeast Asian mangoes and globally traded mangoes.

\begin{tabular}{|c|c|c|c|c|c|c|c|c|}
\hline Attribute & 'Chokanan' & $\begin{array}{c}\text { 'Golden } \\
\text { Phoenix' }\end{array}$ & $\begin{array}{c}\text { 'Water } \\
\text { lily' }\end{array}$ & 'Alphonso' & 'Ataulfo' & 'Haden' & 'Keitt' & $\begin{array}{c}\text { 'Tommy } \\
\text { Atkins' }\end{array}$ \\
\hline $\begin{array}{c}\text { Firmness } \\
(\mathrm{N})\end{array}$ & $12.67^{\mathrm{a}}$ & $9.53^{\mathrm{a}}$ & $7.50^{\mathrm{a}}$ & $0.93^{\mathrm{b}}$ & $7.84^{\mathrm{c}} / 11.70^{\mathrm{d}}$ & $8.82^{\mathrm{c}}$ & $5.30^{\mathrm{e}}$ & $5.88^{\mathrm{c}}$ \\
\hline & & & & & & & & \\
SSC (\%) & $16.80^{\mathrm{a}}$ & $20.30^{\mathrm{a}}$ & $18.55^{\mathrm{a}}$ & $19.41^{\mathrm{b}}$ & $18.84^{\mathrm{c}} / 21.60^{\mathrm{d}}$ & $13.87^{\mathrm{c}}$ & $17.30^{\mathrm{e}}$ & $19.54^{\mathrm{c}}$ \\
\hline TA (\%) & $0.26^{\mathrm{a}}$ & $0.19^{\mathrm{a}}$ & $0.12^{\mathrm{a}}$ & $0.01^{\mathrm{b}}$ & $0.56^{\mathrm{c}}$ & $0.10^{\mathrm{c}}$ & $0.20^{\mathrm{e}}$ & $0.18^{\mathrm{c}}$ \\
\hline Hue $^{*}$ & $89.63^{\mathrm{a}}$ & $108.61^{\mathrm{a}}$ & $103.30^{\mathrm{a}}$ & & $85.00^{\mathrm{d}} / 89.80^{\mathrm{c}}$ & $67.42^{\mathrm{c}}$ & & $89.88^{\mathrm{c}}$ \\
\hline $\mathrm{L}^{*}$ & $63.78^{\mathrm{a}}$ & $57.59^{\mathrm{a}}$ & $57.97^{\mathrm{a}}$ & $64.30^{\mathrm{b}}$ & $59.31^{\mathrm{c}} / 75.00^{\mathrm{d}}$ & $57.80^{\mathrm{c}}$ & & $59.53^{\mathrm{c}}$ \\
\hline
\end{tabular}

Note: Subscript letters: (a) Data obtained from the present study; (b) Nambi et al., 2015; (c)

Nassur et al., 2015; (d) Palafox-Carlos et al., 2012; (e) Padda et al., 2011 